\title{
The Role of the Public Broadcaster in Informing Montenegrin Citizens about European Integration with Special Emphasis on Chapter 27
}

\begin{abstract}
As a media outlet established, funded and controlled by the public, the public broadcaster has a special obligation in regard to informing the people about topics of public interest in accordance with professional reporting standards. European integration represents one of these topics, bearing in mind the fact that Montenegro started its journey towards the European Union in 2008. So far, 32 chapters have been opened, excluding Chapter 8 which is related to competition.

In recent years, public opinion polls have shown a decline in the number of Montenegrin citizens who support Montenegro's accession to the EU. This result can be explained by the impact of Brexit and the pessimistic estimates of experts that the European Union is going to fall apart in the near future.

It is clear that the media - above all the public broadcaster - plays an important role in the process of informing the public on the accession process and shaping public opinion. Therefore, this work shall be dedicated to an analysis of the public broadcaster's reporting on Chapter 27 which is related to the environment and climate change. This chapter was chosen precisely because Montenegro defines itself as an ecological state.
\end{abstract}

Keywords: RTCG, Public Information, Chapter 27, European Union, Environment, Climate change

\section{Introduction}

Since 2008, EU membership has been a topic that draws the attention of the media - or more precisely of the public - and politicians quite often

^ Nataša Ružić - University of Montenegro, e-mail: nruzic@ucg.ac.me, ORCID: 0000-0002-8965-0012. 
use it in their populist statements. Whereas the ruling structure promises prosperity in every field and a better standard of living, claiming that Montenegro is the regional leader in European integration, opposition politicians use this topic to criticise the current government, stating that the European Union is not satisfied with Montenegro's progress in certain chapters and that corruption, crime and violations of the rule of law remain the main problems in Montenegrin society. The media have picked one of the two sides, depending on the editorial policy, using media framing as the most frequent form of manipulation, i.e. they tend to pick commentators whose opinions are already known and correspond to the editorial policy of the particular outlet. Such a manner of reporting contributes to the spread of disinformation among the public in regard to Montenegro's steps forwards/backwards on the path to the European Union.

In the last year, due to Brexit, there has been a decline in the citizens' trust in the European Union. A survey by the non-governmental organisation CEDEM, which was conducted last year in July on a sample of 1002 respondents, showed that $58 \%$ of the citizens supported Montenegro's membership in the EU, $23 \%$ were against, while $19 \%$ had no opinion on the matter. ${ }^{1}$ A survey by the same organisation, conducted in the year before, i.e. in March 2018, on a sample of 1004 respondents, established that Montenegro's European course was supported by $67.9 \%$ of the citizens, whereas only $9 \%$ didn't have a clear opinion on this matter. ${ }^{2}$ This means that, in the past two years, there has been a $10 \%$ increase in the number of citizens who are having second thoughts regarding Montenegro's EU accession and who have moved to the "undecided" category.

\section{The Role of the Media on Montenegro's Path to the EU}

After gaining independence in the referendum held on 21 May 2006, Montenegro started building its relations with the European Union on its own. The Stabilisation and Association Agreement was signed in October 2007 and it was unanimously ratified in the Montenegrin Parliament. An interim trade agreement with the EU, as well as an agreement on visa facilitation entered into force in January 2008, which was followed by the adoption of the National Programme for Integration of Montenegro in the EU in June of the same year. ${ }^{3}$ Montenegro has expressed its desire

1 Političko javno mnjenje Crne Gore, jul 2019 (Political Public Opinion Poll in Montenegro, July 2019), Podgorica, 18.07.2019.

2 Političko javno mnjenje, mart 2018 (Political Public Opinion Poll in Montenegro, March 2018), Podgorica, 10.04.2018.

3 D. Abazović, R. Markić, B. Čobaj, A. Camaj, E. Mehmeti, Evropa za sve (Europe for All), NGO New Horizon, Ulcinj, 2009, p. 38. 
to become a part of the European family by submitting a request for membership in the European Union on 15 December 2008. After two years, Montenegro obtained the status of a candidate state. ${ }^{4}$ In October 2011, the European Commission recommended the launch of accession negotiations, and the chief negotiator for the conduct of the negotiations with the EU was appointed in December of the same year. ${ }^{5}$ The negotiations started in June 2012, with 32 chapters being opened since 18 December 2012. From 2011 to 2018, the negotiations were conducted by the Ministry of European Affairs. It was abolished in May 2018, while the competences of the Ministry were assumed by the newly-formed European Integration Office.

For the purpose of informing the public as well as possible about the negotiation process, several communication strategies were adopted starting from 2004. The document "Communication Strategy for Informing the Public on the European Union and Preparations of Montenegro for Membership 2010-2014" stated that the goals of the strategy were - informing the wider public, education, promotion and mobilisation of the public through the provision of reliable, accessible information in a clear language. ${ }^{6}$ Several target groups can be distinguished in the communication strategy: multipliers, youth and change-sensitive groups. The multipliers include the media, MPs, political parties, NGO sector, educational institutions, religious organisations and local associations. ${ }^{7}$ The youth target group encompasses the entire school system, while the change-sensitive groups comprise retired persons, population from rural areas, unemployed persons, as well as persons with disabilities. The communication strategy did not just cover the national, but also the international public, for the purpose of improving the country's image and informing about the accession negotiations. The international public includes foreign diplomatic missions, Delegation of the European Union to Montenegro, international organisations, foreign media. ${ }^{8}$ The main communication channels are print and electronic media, Internet, public events, info centres, etc. Already the next Strategy for Informing the Public about the European Union and Membership Preparations 2014-2018

${ }^{4}$ Crna Gora \& EU (Montenegro and EU), Ministry of Foreign Affairs and European Integration, Podgorica, 11.11.2014, pp. 5, 7.

5 Ibidem.

6 Komunikaciona strategija za informisanje javnosti o Evropskoj uniji i pripremama za članstvo za period 2010-2014 (Communication Strategy for Informing the Public on the European Union and Preparations of Montenegro for Membership 2010-2014), Government of Montenegro and Ministry of European Integration, Podgorica, 14.01.2014, p. 11.

${ }^{7}$ Ibidem, p. 15.

8 Ibidem, p. 17 
recognised a series of shortcomings in the previous communication strategy, along with implementation problems. The following problems were recorded: lack of communication strategy implementation budget, poorly defined internal communication channels; insufficient public knowledge about the benefits of EU membership, as well as about the negotiation team members; same messages for all target groups; inaccessibility of information for persons with disabilities. ${ }^{9}$ The target groups remained the same as in the previous strategy, though the communication channels became more diverse: press releases, press conferences, working breakfasts with journalists, newsletters, brochures, handbooks, radio shows, columns, interviews for all types of media, paid advertisements, video clips, films, quizzes, photographs, mobile applications, video messages, sign language interpretation of media contents. ${ }^{10}$ In terms of internal communication, it was proposed to establish a special body which would monitor the implementation of the communication strategy, as well as improve communication within the Government, the Parliament and other state institutions, i.e. an Operational Structure and a Consultative Body were formed. The Public Information Strategy on Montenegro's Accession to the European Union 2019-2022 points to the correlation between the level of public awareness and the degree of support for European integration - the better informed, the more supportive citizens become of the integration process. ${ }^{11}$ The last strategy indicates the problems of internal communication in the Government, but also external communication aimed at the public. One of the identified problems was the lack of specialisation among journalists to report on this topic, which was reflected in the manner of reporting about European integration.

\section{RTCG's Reporting on Chapter 27}

European integration is an essential topicin theinformativeprogrammes and texts in media with various editorial policies. Montenegrin media operate under political and economic pressures, as illustrated by the Press Freedom Index published by Reports Without Borders, according to which Montenegro is ranked $105 .{ }^{12}$ Montenegro's media market is small, with

9 Strategija informisanja javnosti o pristupanju Crne Gore Evropskoj uniji 20142018 (Strategy for Informing the Public about the European Union and Membership Preparations 2014-2018), Podgorica, 14.12.2014, p. 13.

10 Ibidem, pp. 22, 23.

11 Strategija informisanja javnosti o pristupanju Crne Gore Evropskoj uniji 20192022. godina (Public Information Strategy on Montenegro's Accession to the European Union 2019-2022), Podgorica, 11.01.2019, p. 14.

$12 \mathrm{https}$ //rsf.org/en/ranking\# (access 21.04.2020). 
four daily papers, one weekly magazine, 20 television stations, 52 radio stations and 60 web portals fighting for their share of the audience and the marketing profits. ${ }^{13}$

Eighteen years ago, Montenegrin citizens got their own media outlet, i.e. the Public Broadcaster, which was created by the transformation of the former state-owned media outlet and which has a privileged status in comparison to private commercial media, for it has a regular budget allocation in the amount of $0.3 \%$ of the GDP. Despite the recommendations of the Parliamentary Assembly of the Council of Europe in relation to the openness of the public broadcaster, RTCG initiated the process of digitalisation and adjustment to audience needs rather late. It was only in 2013 that the RTCG web portal was established, and according to SimilarWeb, it is ranked 31 in Montenegro in terms of the traffic volume. ${ }^{14}$ Having in mind the duties of the Public Broadcaster towards the Montenegrin citizens in regard to information, we have decided to conduct a quantitative analysis in order to establish how much attention $R T C G$ pays to Chapter 27. This chapter was selected because Article 1 of the Constitution of Montenegro proclaims Montenegro to be "a civil, democratic, ecological and a state of social justice, based on the rule of law". ${ }^{15}$

Previous research has shown that $R T C G$ was superficially reporting on European integration, providing the public with facts without context. For example, a quantitative content analysis which was conducted in the period 9-16 May and 20-27 June 2016, focusing on two case studies (Europe Day and Brexit), established that, in a quantitative sense, RTCG paid attention to the celebration of Europe Day, as well as to the UK referendum. In the period 9-16 May, the public broadcaster published 72 texts, but most of the information was published in the form of reports (41) and news (19), i.e. factual genres. ${ }^{16}$ In the week when the Brexit referendum was organised, from 20 to 27 June, 58 pieces of information were published on the RTCG portal. The superficiality of the reporting is illustrated by the predominantly informative genres of news (45) and reports (4), as well as references mainly to statements by official sources of information in $39.65 \%$ of the texts. On the basis of the conducted

13 https://aemcg.org/emiteri-operatori-i-publikacije/?title=\&select-emiter_kategorija $\% 5 \mathrm{~B} \% 5 \mathrm{D}=$ elektronske-publikacije (access 20.04.2020).

${ }_{14} \mathrm{https}: / / w w w . s i m i l a r w e b . c o m / w e b s i t e / r t c g . m e \#$ overview (access 20.04.2020).

15 Ustav Crne Gore (Constitution of Montenegro), Official Gazette of Montenegro, No. 1, 25 October 2007.

${ }_{16}$ N. Ružić, D. Lučić, Crnogorski portali o EU integracijama- činjenice bez konteksta (Montenegrin Portals on EU Integration - Facts Without Context), "Communication and Media”, vol. XIII, no. 42, Faculty of Political Sciences, Belgrade 2016, p. 96. 
research, the authors conclude that the media are providing the audience with information without context, which essentially comes down to the mere reproduction of official statements. Have the media identified and understood their mistakes and have they changed their manner of reporting in 2020? Relying upon the conducted research, we shall presume that RTCG has been reporting superficially on Chapter 27 - environment and climate change. For the purpose of confirming the hypothesis, we have analysed the Tourism and Ecology section from 10 December 2018, when this chapter was opened, to 10 December 2019. In December 2019, the focus of all media shifted to the COVID-19 epidemic, which first struck China, before eventually turning into a global pandemic. The stated period was chosen precisely for these reasons.

Chapter 27 is regarded as the most challenging and the most expensive, comprising ten areas, i.e. water quality, air quality, waste management, environmental protection, climate change, etc. The main question we shall attempt to answer through the analysis is: does the Public Broadcaster deal with the stated problems - and if so, to what degree - with the aim of informing the public about the fulfilment of EU requirements in terms of ecology and climate change?

In the period from December 2018 to December 2019, 264 texts were published in the Tourism and Ecology section. This means that the Public Broadcaster paid a significant amount of attention to this issue, but we must keep in mind that information quantity is not an indicator of information quality, which is why we shall establish the manner in which the Public Broadcaster reported on this important matter, on the basis of genres, authorship and sources.

Table 1. Topics

\begin{tabular}{|l|r|l|c|}
\hline \multicolumn{1}{|c|}{ Topic } & RTCG & \multicolumn{1}{c|}{ Topic } & RTCG \\
\hline $\begin{array}{l}\text { course of negotiations and promotion } \\
\text { of the state's activities }\end{array}$ & 71 & $\begin{array}{l}\text { ecological } \\
\text { crime }\end{array}$ & 20 \\
\hline ceremonies and meetings & 7 & conflicts & 5 \\
\hline waste & 51 & education & 2 \\
\hline water management & 11 & projects & 4 \\
\hline protecting plants and animals & 23 & advertisement & 16 \\
\hline ecological problems & 52 & policy & 2 \\
\hline
\end{tabular}

In the observed one-year period, citizens were able to obtain information on the course of the negotiations, and about the activities and efforts of the state and the NGO sector aimed at improving the situation regarding environmental issues. Thanks to the mentioned actions, readers can learn 
about environmental problems and waste clean-up from 52 and 51 texts, respectively. All this information contains concealed advertising elements, because clean-ups of coastal waste are usually carried out within various projects. The media focused on several environmental problems or potential future environmental problems: pollution of the rivers Tara, Zeta, Lim, high level of air pollution in Pljevlja, military training area on Mount Sinjajevina, devastation of the islet of Mamula, Fort Goražda, etc. Information that has no value is related to projects and overt advertisements for specific facilities and activities of municipal representatives. The advertising of the activities of state authorities implies - among other things - the repeated publishing of the same information on a certain event. For example, four texts were dedicated to eco-ships in the Boka Bay. "Eco-Ships as Public Transportation in Boka", "Eco-Ships Still Not Transporting Passengers in Boka", "Eco-Ships Set Sail in Boka", "First Passengers Satisfied with New Mode of Transport in Boka". In addition, we have recorded the advertising of specific hospitality facilities: "Environmental Protection Award for Regent Hotel" or "Podgorica Gets First Green Hotel", or the activities of NGOs: "Župa u Srcu ${ }^{17}$ Promotes Lukavica".

The analysis concluded that only through the text titled "Single-Use Plastics to Be Banned" were the citizens able to learn about the European directives that are going to be applied in the Law on Waste Management, which prohibits single-use plastic products such as utensils, straws, cups, etc. The EU resorted to this measure because research has shown that $80-85$ per cent of marine debris is composed of plastic. ${ }^{18}$

Table 2. Genre

\begin{tabular}{|l|c|l|c|}
\hline \multicolumn{1}{|c|}{ Genre } & RTCG & \multicolumn{1}{c|}{ Genre } & RTCG \\
\hline News & 197 & Article & 1 \\
\hline Report & 29 & Feature story & 5 \\
\hline Interview & 16 & Hybrid genre & 16 \\
\hline
\end{tabular}

As can be seen in the table above, informative genres (news) are dominant, whereas only 16 hybrid genres were published in this period, along with one article. RTCG made an effort to inform the citizens about key environmental questions through 16 interviews with various people, such as experts, representatives of state institutions, NGO sector, etc.

17 Župa u srcu - name of the NGO.

18 M.M. Pobjeda, MORT: Zabraniće upotrebu jednokratnih plastičnih proizvoda (Ministry of Sustainable Development and Tourism: It will ban the use of disposable plastic products), RTCG, http://www.rtcg.me/vijesti/turizam-i-ekologija/246006/zabranice-upotrebu-jednokratn ih-plasticnih-proizvoda.html (access 3.05.2020). 
Different topics were addressed in the interviews - the public was able to familiarise itself with national park plans, as well as the warnings of experts about the necessity of raising the environmental awareness of the citizens or the warnings about environmental problems such as the disappearance of Lake Biograd ${ }^{19} 130$ years from now. Out of the sixteen interviews, as many as seven were taken from the $M I N A$ news agency, and one from Radio Crne Gore.

In this period, one article was published regarding the environmental problem of the red mud pond and its impact on the inhabitants of the neighbouring areas (Botun and Dajbabe). The journalists addressed various topics through other informative genres as well. For example, reporting from a scientific conference, they presented the opinions of experts on different environmental problems, such as the threat to the Bolje Sestre spring due to gravel exploitation from the coastal part of the Morača River ${ }^{20}$ or they informed the public about the established cooperation, i.e. the memorandum on the protection of the Zeta River signed by representatives of municipalities and representatives of nongovernmental organisations. ${ }^{21}$

\section{Table 3. Text authorship}

\begin{tabular}{|l|c|}
\hline Authorship & RTCG \\
\hline Journalist & 153 \\
\hline Other or the outlet itself & 2 \\
\hline Journalist and other outlet & 97 \\
\hline Not indicated & 12 \\
\hline
\end{tabular}

The majority of texts were signed by initials, whereas a full name was used exclusively in cases of news content convergence, or when features were taken from TVCG or RCG. In this section, we have found eight pieces of information that were taken from Radio Crne Gore and thirteen features from TVCG. Having in mind that the Public Broadcaster possesses two radio stations and three television channels, we may say that the advantages of technological convergence and news content convergence

19 Lake Biograd is a mountain lake in the north of Montenegro, within the scope of the Biogradska Gora national park.

20 I.P., Eksploatacija pijeska ugrožava Bolje sestre (Bolje Sestre Threatened by Sand Exploitation), RTCG, http://www.rtcg.me/vijesti/turizam-i-ekologija/228974/eksploatacija-pijeska-ugrozava-bolje-sestre.html (access 20.04.2020).

21 M.M. Potpisan memorandum o zaštiti rijeke Zete (Memorandum on Zeta River Protection Signed), RTCG, http://www.rtcg.me/vijesti/turizam-i-ekologija/237791/potpisan-memorandum-o-zastiti-rijeke-zete.html (access 24.04.2020). 
are not used to a sufficient degree. The superficiality of the reporting is also illustrated by the fact that 56 pieces of information were taken from the MINA news agency, while 16 were taken from outlets such as Radio Fadran, Boka News, Pobjeda, Antena M, B92, RTV Budva, etc.

\section{Table 4. Graphic accompaniment}

\begin{tabular}{|l|c|}
\hline Graphic accompaniment & RTCG \\
\hline Text only & 2 \\
\hline Text and photo & 183 \\
\hline Text and video & 30 \\
\hline Text and illustration & 48 \\
\hline Text and multiple categories & 1 \\
\hline
\end{tabular}

As many as 262 texts were accompanied by graphic elements. Photographs are by far the most dominant form of visual accompaniment, whereas we find video footage in cases of material taken from TVCG or in cases when citizens or NGOs try to warn the public about environmental problems by means of video footage. For example, the NGO Euromost reacted to the high level of air pollution because of heavy smoke coming from a wood processing plant in Bijelo Polje ${ }^{22}$, while a reader sent photographs showing faecal pollution in the Breznica River near Pljevlja. ${ }^{23}$ During the analysed period, only three readers sent photos or video of potential environmental problems, such as the discharge of filthy water from a cruiser in the Bay of Kotor. Civic journalism is still not present in Montenegrin media despite the sufficient technological equipment of the citizens, so this result comes as no surprise.

Table 5. Graphic accompaniment content

\begin{tabular}{|l|c|}
\hline Graphic accompaniment content & RTCG \\
\hline Quoted person shown & 32 \\
\hline Location of event shown & 37 \\
\hline Quoted person and location of event shown & 37 \\
\hline Quoted person and location mentioned in the text shown & 4 \\
\hline Association with the topic or source & 63 \\
\hline Location/facility mentioned in the text & 89 \\
\hline
\end{tabular}

22 J.B.Č., Iz fabrike u centru BP ponovo kulja dim (Plant in BP City Centre Belching Out Smoke Again), RTCG, http://www.rtcg.me/vijesti/turizam-i-ekologija/236658/izfabrike-u-centru-bp-ponovo-kulja-dim.html (access 20.04.2020).

${ }^{23}$ M.M.Lj.,Fekalijese izlivaju u BreznicuucentruPljevalja (Faeces Discharged in Breznica in Pljevlja City Centre), RTCG, http://www.rtcg.me/vijesti/turizam-i-ekologija/253014/ fekalije-se-izlivaju-u-breznicu-u-centru-pljevalja.html (access 22.04.2020). 
89 photographs show the location or the facility that is mentioned in the text, while reports and features depict the person quoted, as well as the location of the event. All illustrations contain an association with the topic or the source through the logo of a non-governmental organisation, or an image showing a waste pile when speaking of a plastic waste problem.

The texts published in this period include 261 with an informative headline, two with a combined headline and one with a metaphorical headline. An example of the combined headline can be found in the text dedicated to the devastation of Fort Goražda above Kotor: "Goražda Withstood the Test of Time, Will It Withstand Human Irresponsibility?”, whereas the text with the metaphorical headline "Waste 'Suffocating' the Adriatic Sea" deals with the problem of plastic waste in the Adriatic Sea, as can clearly be seen from the headline itself.

\section{Table 6. Sources}

\begin{tabular}{|l|c|l|c|}
\hline \multicolumn{1}{|c|}{ Sources } & RTCG & \multicolumn{1}{|c|}{ Sources } & RTCG \\
\hline $\begin{array}{l}\text { Official representatives of the Government, } \\
\text { ministries, municipalities }\end{array}$ & 61 & Unofficial & 8 \\
\hline $\begin{array}{l}\text { Official representatives of state-owned } \\
\text { companies }\end{array}$ & 36 & $\begin{array}{l}\text { International } \\
\text { organisations }\end{array}$ & 5 \\
\hline $\begin{array}{l}\text { Official sources and international organisa- } \\
\text { tions }\end{array}$ & 10 & NGO sector & 60 \\
\hline Official sources and foreign delegations & 6 & Experts & 18 \\
\hline Official sources and companies & 3 & Companies & 11 \\
\hline Official source and NGO sector & 25 & Primary & 2 \\
\hline Official source, companies and NGO sector & 1 & Secondary & 7 \\
\hline $\begin{array}{l}\text { Official source, international organisations } \\
\text { and NGO sector }\end{array}$ & 2 & Not indicated & 9 \\
\hline
\end{tabular}

In the reporting on Chapter 27, informative genres are dominant, i.e. news and interviews which rely upon a single source of information, whereas we find two or more sources in reports, articles and hybrid genres. Official sources of information prevail and we can find them in 144 texts in the capacity of the only source or one of the sources, followed by the non-governmental sector whose statements were recorded in 88 texts. Official sources in the form of state-owned company representatives include national parks, utility companies, various inspections, the Statistical Office, etc. The Ministry of Sustainable Development and Tourism - or more precisely the Directorate for Environment - is cited as a source of information in 48 texts. The two most active non-governmental organisations which openly point out environmental problems are Ozon 
and Green Home. International organisations such as UNDP or the EU Delegation to Montenegro are found in 17 texts as sources.

\section{Conclusions}

The media have an important role in informing the public about environmental issues, as well as in turning public attention to matters of public interest. Apart from the guiding function, the media may play an important role in educating the public together with experts.

As we have stated at the beginning of the work, all previous research has shown that the media report superficially on the process of European integration. Chapter 27 was no exception to the rule. The following illustrates the superficiality of the reporting: informative genres that dominate without context and media-initiated texts, taking information from other media. Among the 264 published texts, we have found only one article and 16 hybrid genres. The section is used to promote the activities of state authorities and the projects of the NGO sector, which need to ensure visibility for themselves.

At the conference "EU integration process, media freedom and Chapter 27", EU Ambassador to Montenegro Aivo Orav stressed that the role of the media is not only "to channel the voice of citizens, but also to educate them how they can be involved." ${ }^{44}$ Montenegrin citizens are rather passive and lack media literacy skills, so it is clear that the media cannot entirely change the behaviour of the audience, but they can contribute to gradually raise awareness about numerous issues, including environmental ones. Furthermore, the media have a crucial role in the citizens' attitude towards EU integration, because the public's support for this process is directly conditioned by the extent to which they are informed.

\section{References}

Abazović D., Markić R., Čobaj B., Camaj A., Mehmeti E., Evropa za sve (Europe for $A l l$ ), NGO New Horizon, Ulcinj 2009.

Crna Gora $\mathcal{E} E U$ (Montenegro and EU), Ministry of Foreign Affairs and European Integration, Podgorica, 11.11.2014. https://aemcg.org/emiteri-operatori-i-publikacije/?title $=\&$ selectemiter kategorija\%5B\%5D=elektronske-publikacije (access 10.04.2020).

${ }^{24}$ O.Z. Mina, Informacije iz životne sredine plasirati češće i jasnije (Environmental Information to Be Published More Frequently and Clearly), RTCG, http://www.rtcg.me/ vijesti/turizam-i-ekologija/234811/informacije-iz-zivotne-sredine-plasirati-cesce-i-jasnije.html (access 22.04.2020). 
https://rsf.org/en/ranking\# (access 10.04.2020).

https://www.similarweb.com/website/rtcg.me\# overview (access 20.04.2020).

I.P., Eksploatacija pijeska ugrožava Bolje sestre (Bolje Sestre Threatened by Sand Exploitation), RTCG, http://www.rtcg.me/vijesti/turizam-iekologija/228974/eksploatacija-pijeska-ugrozava-bolje-sestre.html (access 20.04.2020).

J.B. Č., Iz fabrike u centru BP ponovo kulja dim (Plant in BP City Centre Belching Out Smoke Again), RTCG, http://www.rtcg.me/vijesti/turizami-ekologija/236658/iz-fabrike-u-centru-bp-ponovo-kulja-dim.html (access 20.04.2020).

Komunikaciona strategija za informisanje javnosti o Evropskoj uniji i pripremama za članstvo za period 2010-2014 (Communication Strategy for Informing the Public on the European Union and Preparations of Montenegro for Membership 2010-2014), Government of Montenegro and Ministry of European Integration, Podgorica, 14.01.2014.

M.M., Potpisan memorandum o zaštiti rijeke Zete (Memorandum on Zeta River Protection Signed), RTCG, http://www.rtcg.me/vijesti/turizami-ekologija/237791/potpisan-memorandum-o-zastiti-rijeke-zete.html (access 24.04.2020).

M.M.Lj., Fekalije se izlivaju u Breznicu u centru Pljevalja (Faeces Discharged in Breznica in Pljevlja City Centre), RTCG, http://www.rtcg.me/vijesti/ turizam-i-ekologija/253014/fekalije-se-izlivaju-u-breznicu-u-centrupljevalja.html (access 22.04.2020).

Mina O.Z., Informacije iz životne sredine plasirati češće i jasnije (Environmental Information to Be Published More Frequently and Clearly), RTCG, http:// www.rtcg.me/vijesti/turizam-i-ekologija/234811/informacije-izzivotne-sredine-plasirati-cesce-i-jasnije.html (access 22.04.2020).

Pobjeda M.M., MORT: Zabraniće upotrebu jednokratnih plastičnih proizvoda (Ministry of Sustainable Development and Tourism: It will ban the use of disposable plastic products), RTCG, http://www.rtcg.me/vijesti/turizami-ekologija/246006/zabranice-upotrebu-jednokratnih-plasticnihproizvoda.html (access 3.05.2020).

Političko javno mnjenje Crne Gore, jul 2019 (Political Public Opinion Poll in Montenegro, Fuly 2019), Podgorica, 18.07.2019.

Političkojavno mnjenje, mart 2018 (Political Public Opinion Poll in Montenegro, March 2018), CEDEM, Podgorica, 10.04.2018.

Ružić N., Lučić D., Crnogorski portali o EU integracijama- činjenice bez konteksta (Montenegrin Portals on EU Integration - Facts Without Context), "Communication and Media", vol. XIII, no. 42, Faculty of Political Sciences, Belgrade, 2016, DOI: https://doi.org/10.5937/comman1111725 . 
Strategija informisanja javnosti o pristupanju Crne Gore Evropskoj uniji 20142018 (Strategy for Informing the Public about the European Union and Membership Preparations 2014-2018), Podgorica, 14.12.2014.

Strategija informisanja javnosti o pristupanju Crne Gore Evropskoj uniji 20192022. godina (Public Information Strategy on Montenegro's Accession to the European Union 2019-2022), Podgorica, 11.01.2019.

Ustav Crne Gore (Constitution of Montenegro), "Official Gazette of Montenegro”, no. 1, 25 October 2007. 